\title{
Evaluation of Thermal Properties of Ferrite Nanoparticles for Magnetic Hyperthermia Treatment
}

\author{
E. I. A. Elbeshir \\ Assistant Professor, Physics of Biomedical Materials, Physics Department, Faculty of Science and Art, Almikhwah, \\ Al-Baha University, P.O.Box. 1988 KSA
}

\begin{abstract}
The thermal properties of $\mathrm{Fe}_{2} \mathrm{O}_{3}, \mathrm{Fe}_{3} \mathrm{O}_{4}$ and $\mathrm{CoFe}_{2} \mathrm{O}_{4}$ nanoparticles (NPs) was evaluated in this study. $\mathrm{Fe}_{2} \mathrm{O}_{3}, \mathrm{Fe}_{3} \mathrm{O}_{4}$ and $\mathrm{CoFe}_{2} \mathrm{O}_{4} \mathrm{NPs}$ exhibited high temperature rise $\left(\mathrm{T}^{\circ} \mathrm{C}\right)$, heating rate $\left(\Delta \mathrm{T} / \Delta t^{\circ} \mathrm{C} / \mathrm{sec}\right)$ and specific absorption rate $(\mathrm{SAR} w / \mathrm{g})$. Induction heater operated at $100 \mathrm{kHz}$ was used. This study indicates that $\mathrm{Fe}_{2} \mathrm{O}_{3}, \mathrm{Fe}_{3} \mathrm{O}_{4}$ and $\mathrm{CoFe}_{2} \mathrm{O}_{4} \mathrm{NPs}$ could be the most suitable for magnetic hyperthermia treatment (MHT).
\end{abstract}

Keywords: Ferrite nanoparticles, hyperthermia, nano technology, thermal properties.

\section{Introduction}

Magnetic hyperthermia treatment (MHT) is a type of the cancer treatment in which the target is exposed to a temperature ranges $42-46{ }^{\circ} \mathrm{C}$, which is found to be more effective to cancer cells than to normal cells. MHT can be used alone to cancer tumor treatment or together with the radiotherapy or the chemotherapy or the surgery. The hazard and the side effect of the radiotherapy, chemotherapy and the surgery greater than the MHT. The MNPs must be studies dependence on two main branches, the first one is the thermal, while the second one is the magnetic properties. Ferrite NPs consisting of an iron oxide can be localization into the center of the tumor cancer by the direct injection or by carried in the bloodstream. The MNPs absorbed heat energy when it targeted by an external magnetic field (MF) and dispersed a heat. MNPs after localization generate heat, raising the temperature of the tumor and resulting in hyperthermia, if an alternating current magnetic field (ACMF) was applied [1-3].

The Deoxyribo Nucleic Acid (DNA) and the Proton molecules size are $(20-200 \mathrm{~nm})$ and $(5-50 \mathrm{~nm})$ respectively, for that the NPs have several potential biomedical applications, that is cause of it size. The NPs can be used in the biomedical as carriers of drug delivery system (DDS) and heat sources for cancer treatment after targeted by the MF[4-7].

In this study, the applicability of various ferrite NPs as drug delivery systems (DDS) and for MHT is investigated by evaluating their thermal properties.

\section{Experiments}

The $\mathrm{Fe}_{2} \mathrm{O}_{3}, \mathrm{Fe}_{2} \mathrm{O}_{3}$ and $\mathrm{CoFe}_{2} \mathrm{O}_{4}$ nanoparticles (NPs) was synthesized by the co-precipitation methods were purchased respectively from RJSITM, IJSR and RJSITM [8-10].

X-ray diffraction (XRD) patterns were recorded using Shimadzu (XRD-6000), target is $\mathrm{Cu}(\lambda=1.4506 \AA)$, voltage is $40 \mathrm{kV}$, current is $30 \mathrm{~mA}$. Divergence, scatter and receiving slit are 1 degree, 1 degree and $0.3 \mathrm{~mm}$ respectively. The range, mode and speed of scanning are 10 - 80, continues and 2 degree / minute respectively. The sampling pitch is 0.02 degree and the preset time is 0.6 second.

An induction heater operated at low frequencies and low powers $(100 \mathrm{kHz}$ and $100 \mathrm{~W})$, was used to study the energy absorption as the heating rate $\left(\Delta \mathrm{T} / \Delta \mathrm{t}{ }^{\circ} \mathrm{C} / \mathrm{sec}\right)$ and the specific absorption rate (SAR $\mathrm{W} / \mathrm{g}$ ) of these NPs were prepared previously.

$\mathrm{Fe}_{2} \mathrm{O}_{3}, \mathrm{Fe}_{3} \mathrm{O}_{4}$ and $\mathrm{CoFe}_{2} \mathrm{O}_{4}$ NPs having various sizes were prepared by co-precipitation method in a dried powder state. To study the temperature rise $\left(\mathrm{T}^{\circ} \mathrm{C}\right)$, the heating rate $(\Delta \mathrm{T} / \Delta \mathrm{t})$ and specific absorption rate (SAR) value of the $\mathrm{Fe}_{2} \mathrm{O}_{3}, \mathrm{Fe}_{3} \mathrm{O}_{4}$ and $\mathrm{CoFe}_{2} \mathrm{O}_{4} \mathrm{NPs}$, a suspension of any NPs alone was prepared by: $1 \mathrm{ml}$ de-ionizing (DI) water $+2 \mathrm{mg}$ of NPs. In the first $1 \mathrm{ml}$ of DI water was exposed to the magnetic induction and no change on the temperature is noted. Then, $1 \mathrm{mg}$ of $\mathrm{Fe}_{2} \mathrm{O}_{3} / \mathrm{Fe}_{3} \mathrm{O}_{4} / \mathrm{CoFe}_{2} \mathrm{O}_{4}$ NPs was added to $1 \mathrm{ml}$ DI water and exposed to the same magnetic induction heating.

\section{Results and Discussion}

To determine the size ' $t$ ' of the $\alpha-\mathrm{Fe}_{2} \mathrm{O}_{3}$ was prepared, from the XRD data, the peaks positions and the full width at half maximum FWAHM 'B' of the three strongest peaks, shown in the table1, were substituted in the Scherrer's formula(1):

$$
t=\frac{K \lambda}{B \cos \theta}
$$

Where; $\mathrm{t}$ is the size of the crystallite, $\mathrm{K} \approx 0.9$ is constant depend on the crystallite shape, $\lambda=1.4506 \AA$ is $\mathrm{x}$-ray wavelength of the $\mathrm{Cu}$ target, $\mathrm{B}$ is full width at half maximum (FWHM) and $\theta_{\mathrm{B}}$ is Bragg's angle [8-10].

The XRD patterns figure 1, figure 2 and figure 3 indexing of the prepared $\mathrm{Fe}_{2} \mathrm{O}_{3}, \mathrm{Fe}_{3} \mathrm{O}_{4}$ and $\mathrm{CoFe}_{2} \mathrm{O}_{4}$ respectively, show that: this samples are cubic. Such the results in the table1 show a small sizes of $\mathrm{Fe}_{2} \mathrm{O}_{3}, \mathrm{Fe}_{3} \mathrm{O}_{4}$ and $\mathrm{CoFe}_{2} \mathrm{O}_{4}$ are 13, 64 


\section{International Journal of Science and Research (IJSR) \\ ISSN (Online): 2319-7064}

Index Copernicus Value (2013): 6.14 | Impact Factor (2014): 5.611

and $8 \mathrm{~nm}$ respectively indicates that: the samples are the nanoparticles NPs [8-10].

Table 1: The parameters of the three strongest peaks in the XRD patterns

\begin{tabular}{|c|c|c|c|c|c|c|c|c|c|c|c|c|}
\hline $\mathrm{NPs}$ & \multicolumn{3}{|c|}{ 2theta deg. } & \multicolumn{3}{c|}{ FWAHM deg. } & \multicolumn{3}{c|}{$\mathrm{d}(\AA)$} & \multicolumn{3}{c|}{$\mathrm{t}(\mathrm{nm})$} \\
\hline $\mathrm{Fe}_{2} \mathrm{O}_{3}$ & 33.1 & 35.6 & 54.0 & 0.14 & 0.16 & 0.10 & 2.7 & 2.5 & 1.7 & 56.7 & 49.9 & 85.4 \\
\hline $\mathrm{Fe}_{3} \mathrm{O}_{4}$ & 35.9 & 63.2 & 30.5 & 0.86 & 0.92 & 0.90 & 2.5 & 1.5 & 2.9 & 9.8 & 10.2 & 9.3 \\
\hline $\mathrm{CoFe}_{2} \mathrm{O}_{4}$ & 35.7 & 62.9 & 57.3 & 0.58 & 0.68 & 0.62 & 2.5 & 1.5 & 1.6 & 13.3 & 12.8 & 13.5 \\
\hline
\end{tabular}

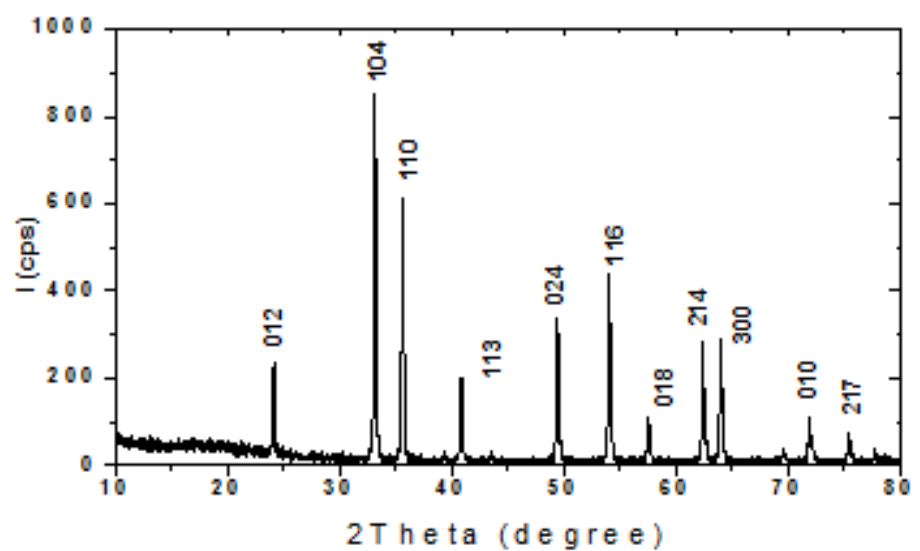

Figure 1: XRD pattern of $\mathrm{Fe}_{2} \mathrm{O}_{3}$

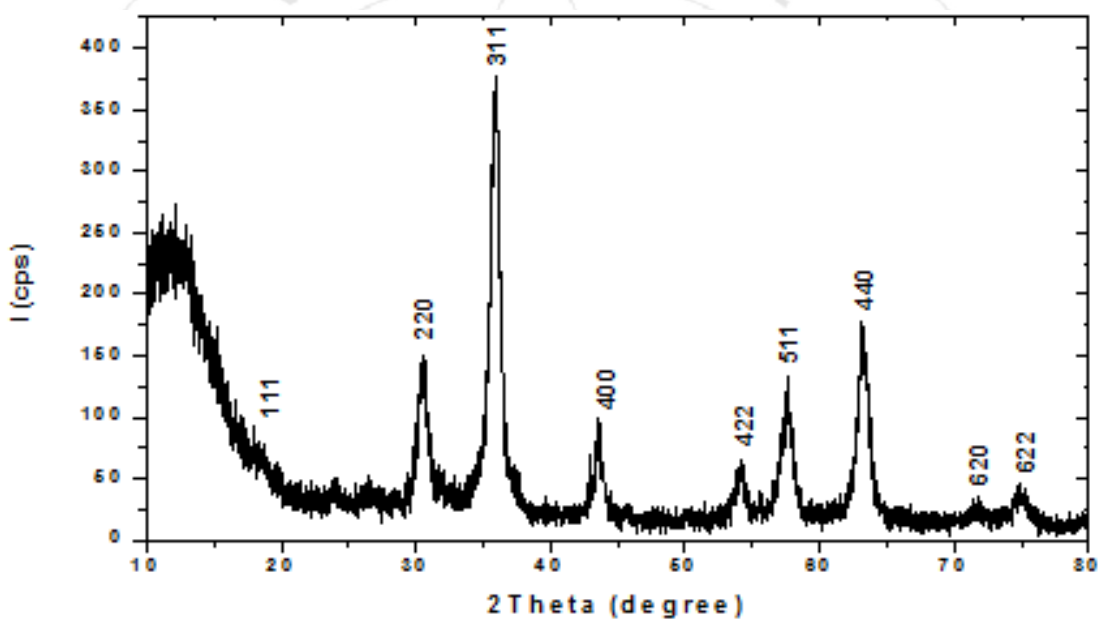

Figure 2: XRD pattern of $\mathrm{Fe}_{3} \mathrm{O}_{4}$

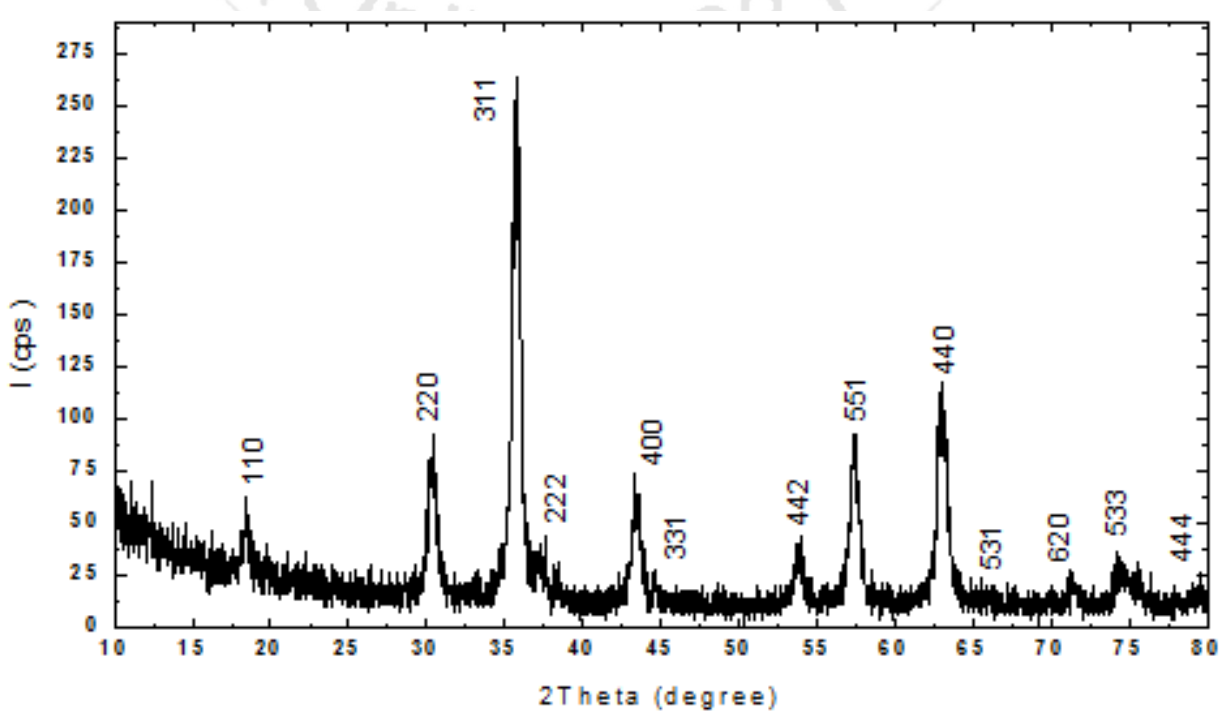

Figure 3: XRD pattern of $\mathrm{CoFe}_{2} \mathrm{O}_{4}$

Volume 5 Issue 2, February 2016

www.ijsr.net

Licensed Under Creative Commons Attribution CC BY 
International Journal of Science and Research (IJSR)

ISSN (Online): 2319-7064

Index Copernicus Value (2013): 6.14 | Impact Factor (2014): 5.611

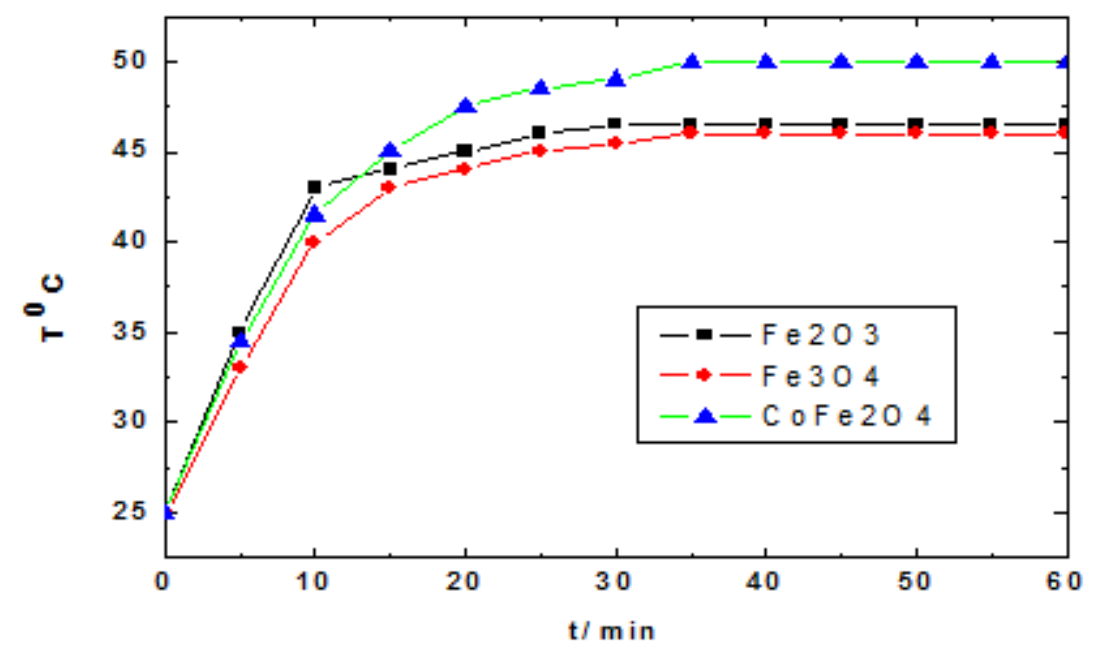

Figure 4: $\mathrm{Fe}_{2} \mathrm{O}_{3}, \mathrm{Fe}_{3} \mathrm{O}_{4}$ and $\mathrm{CoFe}_{2} \mathrm{O}_{4}$ heating rate

Table 2: Thermal properties of the $\mathrm{Fe}_{2} \mathrm{O}_{3}, \mathrm{Fe}_{3} \mathrm{O}_{4}$ and

$\mathrm{CoFe}_{2} \mathrm{O}_{4} \mathrm{NPs}$

\begin{tabular}{|c|c|c|c|}
\hline Sample & $\mathrm{T}^{\circ} \mathrm{C}$ & $\Delta \mathrm{T} / \Delta \mathrm{t}^{\circ} \mathrm{C} / \mathrm{sec}$ & SAR w/g \\
\hline $\mathrm{Fe}_{2} \mathrm{O}_{3}$ & 47 & 0.030 & 63 \\
\hline $\mathrm{Fe}_{3} \mathrm{O}_{4}$ & 46 & 0.025 & 53 \\
\hline $\mathrm{CoFe}_{2} \mathrm{O}_{4}$ & 50 & 0.028 & 58 \\
\hline
\end{tabular}

After 35 minutes the temperature reached 47,46 and $50{ }^{\circ} \mathrm{C}$ for $\mathrm{Fe}_{2} \mathrm{O}_{3}, \mathrm{Fe}_{3} \mathrm{O}_{4}$ and $\mathrm{CoFe}_{2} \mathrm{O}_{4}$ respectively and remained constant up to 60 minutes exposure to the magnetic induction heating. The temperature no longer changed over time when it reached to a certain value because the heat generated by the absorbed electromagnetic energy of $\mathrm{Fe}_{2} \mathrm{O}_{3}$, $\mathrm{Fe}_{3} \mathrm{O}_{4}$ and $\mathrm{CoFe}_{2} \mathrm{O}_{4}$ and the heat released towards the environment were equal that is shown in figure 4.

The SAR value can be calculated by the following equation(2)

$$
S A R=C \frac{\Delta T}{\Delta t} \frac{1}{m_{\text {ferrite }}}
$$

Where; $\mathrm{C}=4.185 \mathrm{~J} \mathrm{~g}^{-1} \mathrm{~K}^{-1}$ is the sample specific heat capacity which is calculated as a mass weighed mean value of magnetite and water. $\Delta \mathrm{T} / \Delta \mathrm{t}{ }^{\circ} \mathrm{C} / \mathrm{sec}$ is the initial slope of the time dependent temperature curve, $\mathrm{m}_{\text {ferrite }}$ is the ferrite content per mg of the sample tube.

There are as good as the linear relations in the first rising of the temperature figure 4 . The linear relation in $0-10$ minutes intervals was used to calculate the $\mathrm{SAR}$ value of the $\mathrm{Fe}_{2} \mathrm{O}_{3}$, $\mathrm{Fe}_{3} \mathrm{O}_{4}$ and $\mathrm{CoFe}_{2} \mathrm{O}_{4}$ NPs by equation above table2.

Figure4 shows that $\mathrm{CoFe}_{2} \mathrm{O}_{4}(13 \mathrm{~nm})$ NPs exhibited the highest temperature rise as compared to the other $\mathrm{Fe}_{2} \mathrm{O}_{3}(64$ $\mathrm{nm})$ and $\mathrm{Fe}_{3} \mathrm{O}_{4}(8 \mathrm{~nm})$ NPs. This was because of the magnetic properties of $\mathrm{CoFe}_{2} \mathrm{O}_{4}, \mathrm{Fe}_{2} \mathrm{O}_{3}$ and $\mathrm{Fe}_{3} \mathrm{O}_{4}$ NPs.

\section{Conclusion}

In this study the high temperature rise $\left(\mathrm{T}^{\circ} \mathrm{C}\right)$, the heating rate $\left(\Delta \mathrm{T} / \Delta \mathrm{t}{ }^{\circ} \mathrm{C} / \mathrm{sec}\right)$ and the specific absorption rate (SAR w/ g) of $\mathrm{Fe}_{2} \mathrm{O}_{3}, \mathrm{Fe}_{3} \mathrm{O}_{4}$ and $\mathrm{CoFe}_{2} \mathrm{O}_{4}$ NPs were evaluated. These NPs exhibited a high temperature rise $\left(47,46\right.$ and $\left.50{ }^{\circ} \mathrm{C}\right)$, the heating rate $\left(0.030,0.025\right.$ and $\left.0.028^{\circ} \mathrm{C} / \mathrm{sec}\right)$ and the SAR value $\left(63,53\right.$ and $58 \mathrm{w} / \mathrm{g}$ ) of $\mathrm{Fe}_{2} \mathrm{O}_{3}, \mathrm{Fe}_{3} \mathrm{O}_{4}$ and $\mathrm{CoFe}_{2} \mathrm{O}_{4}$ respectively and good biocompatibility. Thus, these NPs are suitable for used in the MHT.

\section{References}

[1] Makoto Suto, YasutakeHirota, HiroakiMamiya, AsayaFujita, RyoKasuya, KazuyukiTohji, Balachandran and Jeyadevan (2009), Heat dissipation mechanism of magnetite nanoparticles in magnetic fluid hyperthermia, Journal of Magnetism and Magnetic Materials.

[2] Sophie Laurent, Silvio Dutz, Urs O. Häfeli and Morteza Mahmud (2011), Magnetic fluid hyperthermia: Focus on super-paramagnetic iron oxide nano-particles. Advances in Colloid and Interface Science 166, 8-23.

[3] S. Purushotham and R. V. Ramanujana (2010), Modeling the performance of magnetic nanoparticles in multimodal cancer therapy, JOURNAL OF APPLIED PHYSICS 107, 114701.

[4] Q. A. Pankhurst, J. Connolly, S. K. Jones, and J. Dobson, J. Phys. D: Appl. Phys. 36, R167 (2003).

[5] H. Maeda, G. Y. Bharate, and J. Daruwalla, Eur. J. Pharm. Biopharm. 71, 409 (2009).

[6] H. Nathani and R. D. K. Misra, Mater. Sci. Eng. 94, 228 (2004).

[7] N. Sadeghiani, L. S. Barbosa, L. P. Silva, R. B. Azevedo, P. C. Morais, and Z. G. M. Lacava, Genotoxicity and inflammatory investigation in mice treated with magnetite nanoparticles surface coated with polyaspartic acid, J. Magn. Magn. Mater. 289, 466 (2005).

[8] E. I. A. elbeshir (2015) The thermal properties and the energy absorption of $\alpha-\mathrm{Fe} 2 \mathrm{O} 3$ nanoparticles at low frequency, www.theinternationaljournal.org > RJSITM: Volume: 04, Number: 07, May-2015

[9] E. I. A. elbeshir (2015) Synthesis and Specific Absorption Rate of Fe3O4, Nanoparticles, International Journal of Science and Research (IJSR), ISSN (Online): 2319-7064, Volume 4 Issue 2, February 2015.

[10]E. I. A. elbeshir (2013) Study of $\mathrm{CoFe}_{2} \mathrm{O}_{4}$ nano-particles energy absorption used a new induction heating design operating at $100 \mathrm{~W}-100 \quad \mathrm{kHz}$, www.theinternationaljournal.org > RJSITM: Volume: 02, Number: 05, March-2013. 


\section{Author Profile}

Dr. Eltayeb Ibrahim Ahmed Elbeshir is Assistant Professor, Physics of Biomedical Materials, Physics Department, Faculty of Science and Art, Almikhwah, Albaha University, KSA

Volume 5 Issue 2, February 2016

www.ijsr.net 